\title{
Sztankó Éva*
}

\section{Az acélipar állami támogatási lehetőségei az Európai Szén- és Acélközösség megszünése után}

\begin{abstract}
Az Európai Szén- és Acélközösség (más néven Montánunió) az ún. Föhatóság irányításával a szénbányászat és az acélipar közösségi szintű fejlesztési kereteinek kialakitására tett kísérletet. A Szerződés általános szabályként megtiltotta az állami támogatást, de bizonyos könnyítéseket engedélyezett a válsághelyzetek kezelésére. Ez a gyakorlat lényegesen eltért a Közösséget létrehozó Római Szerződés közösségi támogatási rendszerétől. Az acélipar szabályozása, a hosszú, közel 30 évig tartó válságkezelés után, az ESZAK Szerződés lejártával 2002. július 24.-től átkerült a Római Szerződés hatálya alá. Az állami támogatások új szabályozási keretei lényegesen szükebb mozgásteret engednek a vállalkozásoknak, mint a korábbi gyakorlat. Számolni kell azzal is, hogy az átmenet során lehetnek problémák, mind az elsődleges, mind a másodlagos szabályozás területén. Az Európai Szén és Acélközösség a két ágazat müködését felügyelte, a termelés koordinálásával, pénzügyi kölcsönök és garanciák nyújtásával. Ahhoz, hogy ezt a szerepét el tudja látni, a termelőktől - az alapító okirat felhatalmazása alapján - forgalomarányosan adót szedhetett be. Így feladatai ellátáshoz a közösségi költségvetéstöl független pénzügyi forrással rendelkezett. A Nizzai Szerződésnek az Európai Szén- és Acélközösség megszűnésével foglalkozó Jegyzőkönyve elöirta, hogy a vagyont - a Szén-és Acélkutatási Alap vagyona megjelöléssel - az Európai Közösségnek át kell adni, de az kizárólag a két ágazat fejlesztéseinek támogatására használható fel. Az áttekintés célja, hogy összefogIalóan bemutassa az Unió hatályos állami támogatási szabályait és az acélipari vállalkozások számára igénybe vehetö kedvezmények körét.
\end{abstract}

Az Európai Unió állami támogatási szabályai tágabb értelemben a belső piac megfelelő működéséhez - áruk és szolgáltatások szabad mozgása - kapcsolódnak, szűkebb értelemben pedig a versenypolitika szerves részét képezik az EGK-t létrehozó Római Szerződés 1957-es aláírása óta.

Az állami támogatások befolyásolják és torzíthatják a versenyfeltételeket, ezért alkalmazásuknál arra kell törekedni, hogy a versenyt a lehető legkisebb mértékben korlátozzák, és megfelelő eszközöket biztosítsanak a kitűzött célok eléréséhez. Az állami támogatás nem ingyenes és nem is csodaszer, amelynek segítségével minden probléma azonnal megoldható, az adófizetőknek kell finanszírozniuk, ennek pedig alternatív költségei vannak. Fontos annak tudatosítása is, hogy a magánvállalkozásoknak nyújtott támogatás más területektől vonja el a forrásokat, a rendelkezésre álló állami források

\footnotetext{
* Sztankó Éva a Pécsi Egyetem Közgazdaságtudományi Karának gazdálkodástani Ph.D-hallgatója, a Veszprémi Egyetem Alkalmazott Gazdaságtani Tanszékének óraadó tanára, a Magyar Villamos Múvek Rt. fömunkatársa). E-mail: esztanko@mvm.hu
} 
pedig korlátozottak. A vállalatok müködését a piacgazdaságú országokban alapvetően a piac szabályozza, de lehetnek olyan ágazatok, ahol bizonyos gazdasági és szociális megfontolások miatt ideiglenes jelleggel szükség lehet az állami beavatkozásra.

Az acélipar 50 évig, az Európai Szén- és Acélközösség (ESZAK) fennhatósága alatt ebbe a kategóriába tartozott. Az ESZAK vagy más néven Montánunió, fél évtizeddel az európai integrációt létrehozó Római Szerződést megelőzve jött létre a Párizsi Szerződéssel (1951), melyet a hat alapító EGK tagállam a régió szénbányászatának és vaskohászatának összekapcsolására hozott létre.

A II. világháború után az acélipart egészen a 60 -as évek közepéig stratégiai fontosságúnak tartották, mivel több olyan iparág alapanyagát állította elö, melyek az újjáépítésben meghatározó szerepet játszottak. A gazdaság fejlődésével a stratégiai jelleg megygyengült, azonban a magas kilépési korlátok következtében - tőke- és munkaintenzív technológiák alkalmazása -gazdaságpolitikai fontossága és ehhez szorosan kapcsolódva az állami támogatások jelentős szerepe továbbra is megmaradt. A vas- és acélipart a 70-es évek közepétől kezdve még a 90-es években is a túltermelési válságok jellemezték. A válságok kezelése miatt változatlanul jelentős volt a kormányzat szerepe, de a kormányzati részvétel formái lényeges változásokon mentek keresztül (pl. működési támogatások helyett környezetvédelem, kutatás-fejlesztés támogatása).

Az ESZAK kezdetben az acélhiány csökkentését (az egymással szemben álló német és francia nehézipari kapacitások összehangolásával), később a túltermelés megakadályozását tüzte ki célul. Fennállásának 50 éve alatt sikerült kialakítania egy olyan közösségi szintű szektorális szabályozást a szénbányászatban és az acéliparban, amely komoly szerkezetátalakítási és technológiakorszerüsítési eredményeket tudott elérni.

Az egyezmény hatályát az ESZAK 97. cikkelye 50 évben határozta meg. Ezt követően - 2002. július 24-től - az acélipar szabályozását egyszerüen a Római Szerződés hatálya alá rendelték. A szénbányászatban még átmeneti időre (2010-ig) engedélyezték a külön ágazati szabályozást azért, hogy támogatni tudják az unión belüli energiaforrások felhasználását, hozzájárulva ezzel az energiaimport-függöség csökkentéséhez.

A két szerződés versenypolitikai szabályait - Alapszerződés 81. és 82. cikkely ${ }^{1}$, ESZAK Szerződés 65. és 66. cikkely - az évek során fokozatosan próbálták egymáshoz közelíteni. Ennek eredményeként a Bizottság már az 1990-es éves versenypolitikai jelentésében (European Commission 1990) megállapította, hogy a versenyszabályok bizonyos területein - antitröszt-szabályozás, fúziókontroll - a szerződések a gyakorlati megvalósítást tekintve alig különböznek egymástól. Az állami támogatások kérdésében azonban sokkal markánsabb eltérések mutatkoztak.

A szerződés lejártának közeledtével többször is hangsúlyozták, hogy a közösségi jogi keretek megfelelőek a szénbányászat és az acélipar szabályozási rendszerének beépítéséhez, de számolni kell azzal, hogy az átmenet számos problémát felvethet, mind az elsődleges, mind a másodlagos szabályozás területén (Korah 1997).

A Szerződés 2002. júliusi hatályvesztése után az állami támogatások új szabályozási keretei már lényegesen szűkebb mozgásteret engednek a vállalkozásoknak, mint a korábbi gyakorlat. Ez igaz a szénbányászatra is, ahol a 2002. július 23-án életbe léptetett

${ }^{1}$ Az 1999. május 1-jén hatályba lépett Amszterdami Szerződés - Amszterdami Szerződés az Európai Unióról szóló Szerződés, az Európai Közösséget létrehozó szerződések és egyes kapcsolódó okmányok módosításáról - megváltoztatta a számozást a régi 85. és 86. cikkröl, 81. és 82. cikkre. 
Tanácsi Rendelet értelmében továbbra is ágazati szabályok érvényesek, de a támogatások feltételrendszerét nagyon megszigorították (Council Regulation 2002). Az acéliparban viszont megszünt minden speciális kedvezmény, kizárólag az Alapszerződés állami támogatásokra vonatkozó cikkelyei érvényesek, sőt bizonyos területeken még megszorításokkal is számolni kell.

A következő összefoglaló bemutatja az Unió hatályos állami támogatási szabályait és az acélipari vállalkozások számára igénybe vehető kedvezmények körét az Európai Szén- és Acélközösség megszűnése után. Az átfogó jellegü, nem szektorális szabályozáshoz való alkalmazkodás az 50 évig tartó megkülönböztetett szerep után, bizonyára nagy próbatétel elé állítja a kohászati társaságokat. Arra azonban figyelni kell, hogy a Közösség állami támogatási szabályai folyamatosan változnak. Különösen az Unió 2004-es minden eddiginél nagyobb szabású bővítése után került napirendre az állami támogatáspolitika átfogó reformjának szükségessége, mivel az eddigi szabályok nem kellőképpen átláthatóak a 25 tagállam számára (State Aid Action Plan 2005).

Tekintsük most át azokat a legfontosabb változásokat, melyek a jövőben a vas- és acélipari vállalatok működésére jelentős hatást gyakorolhatnak.

\section{Az acélipar állami támogatása az ESZAK Szerződés hatálya alatt}

Az Európai Szén- és Acélközösség megalakulása az integráció „föpróbájának” volt tekinthető azáltal, hogy az elvben szembenálló francia és német nehézipari kapacitásokat összehangolta. Bizonyos piacszabályozási módszerek kipróbálásával és bevezetésével számos eredményt sikerült elérnie a felügyelt szénbányászat és acélipar korszerüsítésében (Denton 1995).

Az acéliparban (és a szénbányászatban) a Szerződés általános szabályként lényegében megtiltotta az állami támogatás minden formáját, de bizonyos könnyítéseket megengedett. Engedélyezte például Acéltámogatási Kódexek rögzítését azzal a céllal, hogy ágazati szinten azonos kritériumok érvényesüljenek a támogatások elbírálásakor. E mellett az ESZAK 95. \$-a alapján a Bizottság az acélipari vállalkozásokra vonatkozó egyedi döntéseket hozhatott, és a gazdasági szempontok mellett politikai és szociális kritériumokat is figyelembe vehetett, sőt lehetősége volt a támogatást odaítélni a kódextől eltérö esetekben is.

Az ESZAK fennállásának ötven éve alatt hat Acéltámogatási Kódex volt érvényben. A támogatási feltételek - közelítve a közösségi szabályokhoz - egyre szigorodtak, végül a működési támogatást általános szabályként megtiltották. Előtérbe került a kutatás-fejlesztés támogatása és a környezetvédelmi normáknak való megfelelés biztosítása. $\mathrm{Az}$ üzemek részleges bezárásakor megengedték a szociális támogatásokat és a legkevésbé versenyképes vállalkozások valamennyi ESZAK tevékenységének megszüntetéséhez komoly pénzügyi segítséget nyújtottak.

A 2002. július 23-ig érvényben lévő VI. Acéltámogatási Kódex (Commission Decision 1996) az állami támogatások igénybevételének szabályait a következők szerint határozta meg:

1. A támogatásnak szorosan kapcsolódnia kellett egy olyan szerkezetátalakítási programhoz, amely elösegítette a társaság életképességének megőrzését vagy helyreállítását ésszerű időn belül, illetve hozzájárult a régióban a globális kapacitáscsökkentés megvalósításához. 
2. A támogatás nagyságát fokozatosan csökkenteni kellett és csak olyan mértékü lehetett, ami feltétlenül szükséges volt a szerkezetátalakítás alatt a folyamatos müködéshez.

3. Ha a szerkezetátalakítási program előirányozta gyáregységek vagy társaságok bezárását, akkor a bezárásoknak véglegesnek kellett lenniük.

4. A támogatás kedvezményezettje nem juthatott tisztességtelen piaci előnyhöz a ciklikus acélpiaci mozgások idején.

Annak ellenére tehát, hogy az uniós szabályok szerint az állami támogatás minden formája tilos volt, az ESZAK hatálya alatt bizonyos könnyítéseket még az utolsó ágazati Acéltámogatási Kódex értelmezése szerint is megengedtek. Egyedi döntéseket a liberalizáció előrehaladtával már nem hoztak. Kivételesen, fokozatosan csökkenő mértékű állami támogatást nyújthattak szerkezetátalakításra, ha ezzel elősegítették a kedvezményezett társaság működőképességének fenntartását és az adott régió acéltermelő kapacitásának csökkentését. A Kódexben megfogalmazott derogációk már nem elsősorban az uniós vállalatokat segítették, hiszen a szerkezetátalakítás a 90 -es évek végére már befejeződött Nyugat-Európában. A cél elsősorban az újonnan csatlakozó országok acéliparának a fejlesztése volt. Az új tagállamok csatlakozási szerződéseiben megfogalmazták, hogy az állami támogatás bármilyen formája tilos, kivéve az ESZAK Szerződés értelmében megengedett könnyítéseket. Ezzel a lehetőséggel valamennyi jelentősebb acélipari potenciállal rendelkező ország - a 2004-ben csatlakozott tíz ország közül a négy visegrádi ország - élt is, de jelentősebb korszerüsítést nem sikerült elérniük.

A Szerződés lejártának közeledtével egyre több nemzetközileg elismert szakmai szervezet emelte fel a hangját az állami támogatások teljes megszüntetése ellen, ami véleményük szerint könnyen maga után vonhatja a szubvencionálás átcsúszását az illegális eszköztárba.

$\mathrm{Az}$ International Iron and Steel Institute (IISI), - az egyik legnevesebb nemzetközi acélipari szervezet - javasolta, hogy dolgozzanak ki egy új Acéltámogatási Kódexet (IISI Proposal 2002) kizárólag a környezetvédelmi és a szociális kérdések kezelésére. Ennek a kezdeményezésnek nem lett folytatása.

AZ OECD Acélipari bizottsága szintén többször foglalkozott a kérdéssel, eddig hét találkozón ${ }^{2}$ szorgalmazta az engedélyezhető támogatási kategóriák pontosítását.

A következő támogatások legalizálását javasolta:

1. Az üzembezárások miatt munkanélkülivé váló, vagy korkedvezményesen nyugdíjba menő munkavállalók támogatása a teljes összeg maximum 50\%-ig.

2. Az állami tulajdonú vállalatok privatizációjának megkönnyítése, kizárólag az átalakuló és a fejlődő országokban.

Ezt az elképzelést az Unió is támogatja, mivel a privatizációt a szektor átalakítás kulcselemének tartja (Acts of Accession 2003).

3. Egyszeri támogatás kapacitáscsökkentésre.

4. A környezetvédelmi előírásoknak való megfelelést elősegítő beruházások, fejlesztések.

\footnotetext{
2 A 7. megbeszélésre 2005. január 12-13-án került sor Párizsban. Az első öt megbeszélést 2002 decemberéig tartották, majd ezt követöen lelassult a folyamat.
} 
5. Kutatás-fejlesztés, képzés.

6. Technikai és beruházási segítség az átmeneti és a fejlődő országokban.

Az OECD ugyanis nem tiltaná olyan nemzetközi pénzügyi szervezet létrehozását, amely elősegítheti a modernizációt, és az új életképes acélipari kapacitások felépítését az átmeneti és a fejlődő országokban (OECD Observer 2003).

Ezek a tárgyalások (bár kisebb intenzitással, mint az ESZAK megszünését megelözően), tovább folytatódnak. A kínai gazdaság gyors növekedésének köszönhetően az acéltermékárak 2003. óta folyamatosan emelkednek és a világ egyes régióiban már kapacitáshiány is kialakult. Így nem elképzelhetetlen, hogy a szakmai szervezeteknek sikerül bizonyos eredményeket elérniük a támogatások kérdésében.

\section{Az állami támogatások közösségi szabályai}

Az EU állami támogatásokra vonatkozó politikáját a Római Szerződés 87. cikkelye ${ }^{3}$ határozza meg. A cikkely szerint, az állami támogatás elviekben összeegyeztethetetlen az egységes piac müködésével, ha a vállalatoknak nyújtott kedvezményekkel a versenyt eltorzítják, vagy annak eltorzításával fenyegetnek.

A közösség állami támogatási szabályai csak azokra az intézkedésekre vonatkoznak, amelyek a 87. cikk (1) bekezdésében szereplő valamennyi követelménynek egyszerre eleget tesznek.

E követelmények a következők:

1. Állami források juttatása

Az állami támogatási szabályok azokra az intézkedésekre vonatkoznak, amelynek során állami forrásokat osztanak szét (országos, regionális, helyi hatóságok, állami bankok, alapítványok stb.).

Ezen túlmenően nem feltétlenül szükséges, hogy a támogatást maga az állam nyújtsa, lehet az állam által kijelölt nyilvános, vagy magánközvetítő-szervezet is.

A támogatást magában foglaló pénzügyi juttatásoknak sok formája lehetséges: pl. vissza nem térítendő támogatások, kamat-visszatérítések, kezességvállalások, gyorsított értékcsökkenési leírások engedélyezése, tőkejuttatások.

2. Gazdasági elöny

A támogatásnak olyan gazdasági előnyt kell jelentenie, amelyben a kedvezményezett piaci körülmények között nem részesülne. Például:

a. a vállalat piaci ár alatti áron vásárol, vagy bérel köztulajdonban lévő területet;

b. a vállalat piaci árnál magasabb áron ad el területet az államnak;

c. a vállalat kedvezményesen, költségfizetés nélkül jut hozzá infrastruktúrához;

d. a vállalkozás a magánbefektetőnél elérhetőnél kedvezőbb feltételekkel kap kockázati tőkét az államtól. 


\section{Szelektivitás}

A támogatásban csak bizonyos kedvezményezett kör részesülhet. A „szelektivitás” különbözteti meg az állami támogatást az „általános intézkedésektől”, vagyis az olyan intézkedésektől, amelyek általánosan, a tagállam valamennyi ágazatában működő összes vállalatra megkülönböztetés nélkül vonatkoznak.

$\mathrm{Az}$ is kimeríti a szelektivitási követelményt, ha a program a tagállam csak egy részterületén müködik (ez érvényes valamennyi regionális és ágazati támogatásra).

4. A verseny és a kereskedelem befolyásolása

A támogatás potenciálisan befolyásolhatja a tagállamok közötti versenyt és a kereskedelmet. Az is elegendő, ha kimutatható, hogy a kedvezményezett valamilyen gazdasági tevékenységet végez és a tagállamok közötti kereskedelmet lebonyolító piacon müködik.

A Bizottság - a Szerződés által ráruházott - feladata a tagállamok javasolt és létező állami támogatási intézkedéseinek nyomon követése annak biztosítására, hogy azok ne torzíthassák a Közösségen belüli versenyt és kereskedelmet. Az Unió területén, valamennyi vállalkozás számára azonos feltételeket kell biztosítani, függetlenül attól, hogy melyik tagállamban van a telephelyük. A vállalatoknál alkalmazott különböző támogatási módszerek teljes körü ellenőrzése és figyelemmel kísérése azonban szinte lehetetlen feladat elé állítaná az ellenőrzésért felelős Bizottságot, ezért a szabályok csak azokra az intézkedésekre vonatkoznak, amelyek az előzőekben felsorolt összes feltételnek megfelelnek. A Közösség állami támogatási szabályai tehát széles területet átfognak, de csak bizonyos határok között.

\section{Az állami támogatás tilalma alóli kivételek}

A 87. cikk (1) bekezdése szerint azok az állami támogatási intézkedések, amelyek kielégítik a fentiekben leírt valamennyi követelményt, elviekben, összeegyeztethetetlenek a közös piac müködésével. Az összeegyeztethetetlenség elve azonban nem jelent teljes mértékü, általános tilalmat. A Római Szerződés 87. cikk (2) és (3) bekezdései részleteznek számos olyan esetet, amelyekben az állami támogatás elfogadhatónak tekinthető. A mentesítési lehetőségek egyik csoportja automatikusan megadható, míg a másik része a Bizottság mérlegelési jogkörébe tartozik.

Az acéliparnak nyújtható támogatások köre elviekben elképzelhető a következő területeken, a gyakorlati lehetőségek viszont ennél sokkal szűkebbek.

Automatikus mentesség (csak értesítési kötelezettség van):

- 87. cikk (2)(b) bekezdés: természeti csapások vagy más rendkívüli események által okozott károk helyreállítására nyújtott támogatások.

Bizottsági jóváhagyáshoz kötött mentesség:

- 87. cikk (3)(a) bekezdés: a szokatlanul alacsony életszínvonallal, vagy jelentős foglalkoztatási gonddal küzdő térségek gazdaságának fejlesztését előmozdító támogatások.

A közösségi szinttől elmaradott régiók támogatása.

- 87. cikk (3)(b) bekezdés: a közös európai érdekeket szolgáló fontos projektek megvalósításának támogatása (pl. környezetszennyezés megszüntetése). 
- 87. cikk (3)(c) bekezdés: meghatározott gazdasági tevékenységek vagy gazdasági területek fejlesztésének előmozdítása, ahol a támogatás nem befolyásolja a kereskedelmet a közösségi érdek ellenében.

A nemzeti átlagnál fejletlenebb régiók támogatása (pl. képzés, környezetvédelem, kis- és középvállalkozások szerkezetátalakítása, kutatás-fejlesztés).

- 87. cikk (3)(e) bekezdés: olyan egyéb támogatások, amelyet a Tanács a Bizottság javaslata alapján minősített többséggel elfogad. (Ilyen támogatásra eddig csak a hajóépító-iparban volt példa.)

A kizárólagos hatáskör gyakorlásakor a Bizottság a vállalat méretétól, elhelyezkedésétől, az érintett iparágtól és a támogatás céljától függően speciális bírálati szempontokat érvényesíthet.

A Szerződés tehát megengedi a kifejezett kivételeket az állami támogatás tilalma alól olyan esetekben, amikor a javasolt támogatási programok az Unió egészének szempontjából előnyösek lehetnek. Az állami támogatás összeegyeztethető a Szerződéssel, ha teljesíti a világosan megfogalmazott közérdekü célokat, és nem torzítja a Közösségen belüli versenyt és kereskedelmet a közös érdekkel ellentétes mértékben. Sőt, az állami támogatási intézkedések esetenként a közös érdekű célok hatékony megvalósításának eszközei lehetnek, mivel korrigálhatják a piaci hiányosságokat, javítva ezáltal a piacok müködését.

Az előző kivételeknek a léte igazolja a tervezett állami támogatási intézkedések bizottsági felülvizsgálatát, amint arról a Szerződés 88. cikke rendelkezik. Szintén ez a cikk rendelkezik arról, hogy a tagállamoknak be kell jelenteniük a Bizottságnak az állami támogatási tervezeteket még a terv megvalósítása előtt. A Bizottságnak kizárólagos hatásköre van annak eldöntésére, hogy a javasolt állami támogatás kivételnek minősíthetö-e, vagy pedig az érintett államnak meg kell szüntetnie, vagy módosítania kell a támogatást.

\section{Az állami támogatások csoportosítása és a vonatkozó közösségi szabályok}

1. Regionális támogatások

- A 87. cikk (3)(a) bekezdése olyan területeket céloz meg, amelyek az EU átlagánál fejletlenebbek. A NUTS II ${ }^{4}$ szintű nagy régiók tartoznak ide, ahol a vásárlóerő-paritáson mért egy före jutó bruttó hazai termék az EU átlag 75\%-nál kevesebb.

- A 87. cikk (3)(c) bekezdés az egyéb, nemzeti szinten elmaradott régiók támogatásra vonatkozik (NUTS III besorolás, megyei szint). Az erre a kivételre jogosult régiók listáját, tagállami javaslat alapján, ugyancsak a Bizottság dönti el. Célja a régiók felzárkóztatásának elősegítése, leszakadásuk megakadályozása. A támogatásnak összhangban kell lennie a regionális állami támogatásról szóló közösségi iránymutatással (Guidelines 1998) ${ }^{5}$.

\footnotetext{
${ }^{4}$ A statisztikai célú területi egységek közös nomenklatúra (NUTS) rendszerének reformja folyamatban van. Be kívánják vezetni a NUTS negyedik szintjét is a kistérségek besorolására.

${ }^{5}$ Az iránymutatás hatálya nem terjed ki a szénbányászatra, az acéliparnál pedig a speciális ágazati szabályozást is figyelembe kellett venni 2002. július 23-ig.
} 


\section{Beruházási támogatás}

Új termelő beruházás létesítéséhez és meglévő bővítéséhez is kapcsolódhat regionális támogatás, a nemzeti jogszabályokban meghatározott feltételekkel. Magyarország egész területe jogosult regionális támogatásra, de nem azonos mértékben. A jogosultság mértékét a Bizottság által jóváhagyott regionális térkép tartalmazza (Kormányrendelet 2004). A támogatás intenzitása ${ }^{6}$ Budapesten (35\%) és Pest megyében $(40 \%)$ a legalacsonyabb, a Nyugat Dunántúlon $45 \%$, a többi régióban $50 \%$.

Regionális beruházási támogatás nyújtható a kis- és középvállalkozási és a foglalkoztatási csoportmentességi rendeletek alapján (Commission Regulation 2001:33).

A csoportmentességi rendeletek célja a támogatásnyújtási feltételek egyszerüsítése. A jóváhagyás kizárólagos joga a tagállamok feladata, így nincs szükség a Bizottság és a tagállamok közötti hosszas előzetes egyeztetésre. A tagállamok mentesülnek a bejelentési kötelezettség alól, amennyiben a támogatást a rendeletekben foglaltak alapján nyújtják.

Csoportmentességi rendeletek ${ }^{7}$ (Council Regulation 1998) vannak érvényben az ún. de minimis támogatásokra, a kis- és középvállalkozások, a $\mathrm{K}+\mathrm{F}$, a környezetvédelem, a foglalkoztatás és a képzés támogatására.

A nagyberuházásokat - 50 millió eurót meghaladó elszámolható költségű beruházások - csökkentett intenzitással, az Unió multiszektorális keretszabálya (Communication 2002:8) alapján lehet támogatni, de az acéliparra speciális szabályok vonatkoznak. A Bizottság a közös piaccal összeegyeztethetetlennek tartja az acélipari társaságok támogatását ezen a jogcímen. Pontosan definiálja az acélipari termékek körét (Commission Regulation 2031/2001:1), és a felsorolásban nem csak azok termékkategóriák találhatók meg, amelyek az ESZAK hatálya alá tartoztak.

Az Európai Szén-és Acélközösség (ECSC) az acéltermékeket az ún. ESZAK és a nem ESZAK termékkategóriákba sorolta. Ez képezte az alapját a támogatási igényeknek. A specifikáció forma és nem minőség szerinti megkülönböztetést tartalmazott. Az egyszerủ carbon acéltól kezdve a rozsdamentes, magasan ötvözött acélokig minden megtalálható volt az ún. ESZAK termékkategóriában.

A magyarázat szerint az Unióban az acélipar konszolidációjának befejeződése után is vannak felesleges kapacitások, így nem indokolt újabb beruházások indítása. A regionálisan kialakult válságokat pedig az iparág közel 30 éves szerkezetátalakítása során sikeresen kezelték, ezért további regionális támogatásra már nincs szükség. Az ESZAK Szerződés megszűnésével az ágazatnak a belső piaci versenyszabályok szerint kell müködnie, többé már nincs kivételezett helyzetben.

Ez a szigorú korlátozás kiterjed a kis- és középvállalkozások részére nyújtható csoportmentességi rendeletben foglalt regionális nagy összegü egyedi támogatásokra is (Comission Regulation 33. 6. cikkely).

A nagy összegű egyedi támogatásokat a csoportmentességi rendelet föszabályától eltéröen, engedélyeztetni kell a Bizottsággal.

\footnotetext{
6 Támogatási intenzitás: a támogatástartalom és az elszámolható költségek jelenértértének hányadosa százalékban kifejezve. A támogatástartalom számítása a 85/2004 (IV. 19.) kormányrendelet Il. számú mellékletében foglalt módszer szerint történik.

7 A 994/98/EK Tanácsi Rendelet hatalmazza fel a Bizottságot arra, hogy egyes támogatási területeken csoportmentességi rendeleteket alkosson.
} 
Egy támogatás akkor nagy összegü, ha:

- a projekt elszámolható költsége eléri a 25 millió eurót és a nettó támogatási intenzitás eléri az érintett területre vonatkozó regionális támogatási térképen meghatározott támogatási intenzitás $50 \%$-át,

- vagy a teljes bruttó támogatás legalább 15 millió euró.

Ezekkel a megszorításokkal az acélipari tevékenységet folytató vállalkozások gyakorlatilag teljesen ki vannak zárva a regionális támogatási lehetőségekből.

\section{Horizontális támogatások}

A horizontális támogatások regionális és ágazati szelektivitás nélkül részesítenek előnyben bizonyos tevékenységeket. Céljuk, olyan problémák kezelése, amelyek bármelyik iparágban és régióban keletkezhetnek.

$\mathrm{Az}$ acéliparban állami támogatások csak ezen a jogcímen vehetők igénybe, de a lehetőségek nem terjednek ki minden kategóriára.

Az Unión belül az acélipar szerkezetátalakítása már lezajlott, így szerkezetátalakításra és regionális beruházásra támogatás nem adható, de a többi horizontális jogcím alapján elviekben odaítélhető.

A Bizottság eddig a következő támogatási kategóriákra vonatkozóan fogadott el a követelményeket tartalmazó keretszabályokat vagy iránymutatásokat:

- Kis- és középvállalkozások támogatása (Commission Regulation 2004, 2001:33) ${ }^{8}$

Az adható támogatások körét csoportmentességi rendeletek szabályozzák. Támogatható: a beruházás, a tanácsadás, a kutatás-fejlesztés, a vásárokon és kiállításon való részvétel.

Regionális beruházási támogatás kohászati cégeknek nem adható!

- Kutatás-fejlesztési támogatás (Information 1996)

Adható alapkutatásra, ipari kutatásra, kísérleti fejlesztésre.

A kis- és középvállalkozásoknak csoportmentesség adható a $\mathrm{K}+\mathrm{F}$ támogatásokra, és így mentesülhetnek a Bizottság felé történő bejelentési kötelezettség alól (Commission Regualtion 2004) (pl. megvalósíthatósági tanulmányok, szabadalmi jogok megszerzésének költségei).

- Környezetvédelmi támogatás (Community 2001)

Támogatás adható a kis- és középvállalkozásoknak az új közösségi szabványokhoz való alkalmazkodást elősegítő beruházásokhoz (a támogatás az elszámolható költségek maximum 40\%-át érheti el).

Elszámolható költség lehet pl. a szennyezett ipari létesítmények rehabilitációja, a tevékenység környezetvédelmi okból történő áthelyezése, a hulladékgazdálkodás és az energiatakarékosság ösztönzése.

- Szerkezetátalakítási támogatás (Community 2004)

$\mathrm{Az}$ acélipar nem részesülhet ebben a támogatásban.

\footnotetext{
${ }^{8}$ A KKV-k csoportmentességi rendeletének (70/2001/EK) módosítása (364/2004/EK) a támogatások körét kibővítette a K+F támogatásokkal.
} 
- Foglalkoztatási támogatás (Commission Regualtion 2002)

Csoportmentesség adható munkahelyteremtésre, megváltozott munkaképességü munkavállalók foglalkoztatására, többletköltségek támogatására.

- Képzési támogatás (Commission Regulation 2001:20)

- Kockázatitőke-tevékenység (Information 2001)

Támogatás adható: a befektetők részére, az intézkedést megvalósító alap részére, vagy a befektetésre váró vállalkozásoknak.

Elméletileg nincsenek kizárva a volt ESZAK szerződés hatálya alá tartozó vállalkozások, de a gyakorlatban az eddigi ágazati innovációs fejlesztések nem keltették fel ezen befektetöi kör érdeklödését.

\section{3. Ágazati támogatások}

Míg az állami támogatásokra vonatkozó horizontális szabályok általánosságban véve minden ágazatot lefednek, egyes szektorokra különleges szabályok vonatkoznak.

A Bizottság a 70-es évek olajválságai után speciális szabályokat fogadott el a komoly gazdasági és szociális problémákkal küzdő ún. érzékeny ágazatok állami támogatására (pl. szénbányászat, acélipar, textilipar, gépjármügyártás, hajógyártás), melyre az Alapszerződés 87. cikk (3) c. bekezdése alapján volt lehetősége.

Akkor lehetett különleges támogatási szabályokat bevezetni, ha az ágazatok megfeleltek a következő feltételek valamelyikének:

- Az adott ágazat vállalatai nem képesek önerőből a szerkezetátalakítás megvalósítására (pl. szénbányászat).

- A dinamikusan fejlődő ágazat egyre bővülő piaci lehetőségeinek kihasználáshoz komoly fejlesztésekre van szükség, melyet állami segítség nélkül nem tud megvalósítani (pl. gépjármügyártás).

- Az ágazat müködésének fenntartásához szükséges a Közösségen kívüli versenytorzító intézkedések gazdasági hatásainak semlegesítése a közösségen belül (pl. hajóépítő-ipar, textilipar).

- A kapacitásfelesleg megszüntetése miatti jelentős többletköltségek és a szociális kérdéseket kezelése meghaladja a adott ágazat vállalatainak lehetőségeit (acélipar).

- Külön szerződés is elöírhatja az ágazat kiemelt kezelését (pl. mezőgazdaság, halászat, szénbányászat, acélipar).

A kiemelt ágazatok általánostól eltérő támogatási szabályai a piaci helyzet függvényében folyamatosan változnak és általában szigorúbbak, mint a többi iparágra vonatkozóak. A növekvő termelést eredményező beruházások támogatását a legtöbb esetben erősen korlátozzák vagy megtiltják. Az érzékeny ágazatok jelenlegi szabályai átdolgozás alatt vannak, és jelentősen változnak a jövőben. Az előzőekből már ismert, hogy a szénbányászatra továbbra is az ágazati szabályok érvényesek átmenetileg 2010-ig, de az acélipar az ESZAK megszűnésével kikerült ebből a körből.

\section{Az igénybe vehető állami támogatási lehetőségek az acéliparban}

Az elöző szabályokat figyelembe véve, a következőkben foglalhatók össze az acéliparban nyújtható állami támogatási lehetőségek: 
1. A regionális támogatás (Communication 2002:8) tilos, és ez a tiltás kiterjed a kis- és középvállalkozások csoportmentességi rendelete alapján adható regionális nagy összegü egyedi támogatásokra is (Commission Regulation 70/2001:33).

2. A megmentési és szerkezetátalakítási támogatás tilos (Community 2004).

3. Az ESZAK hatálya alatt a környezetvédelmi támogatás megengedett volt, a közösségi környezetvédelmi iránymutatás és az Acélipari Kódexekben foglaltak alapján (Community 1998; Commission Decision 1996). A szerződés lejártát követően, már az új környezetvédelmi iránymutatás (Community 2001) előírásainak kell megfelelnie az ágazatnak. A leglényegesebb különbség a két szabályozás között az, hogy az új közösségi szabványokhoz való alkalmazkodást elősegítő beruházásokhoz már nem vehetö igénybe állami támogatás, kivéve bizonyos feltételek teljesülésekor a kis- és középvállalkozásokat.

4. A kutatás-fejlesztési támogatás továbbra is megengedett (Information 1996).

5. A bezárási támogatás megengedett 2009. december 31-ig (Communication 2002:21). (Külön Bizottsági közlemény foglalkozik az acéliparral.)

6. A kis- és középvállalkozások beruházásai az EU csoportmentességi rendelete (Commission Regulation 2001:33) alapján támogathatók. A megvalósítás helyétől függően a nettó támogatás intenzitása nem haladhatja meg a 15\%-ot a kisvállalkozásoknál, és a 7,5\%-ot a közepes méretủ vállalkozásoknál.

7. Csekély összegü (de minimis) támogatás adható a 69/2001/EK (Commission Regulation 2001:30) csoportmentességi rendelet alapján.

Csekély összegü támogatás akkor nyújtható, ha a támogatástartalom 3 év alatt kisebb, mint 100.000 euró. Összegük miatt a versenytorzító hatás nem jelentős, de a gazdasági ösztönző hatás főleg a kis- és középvállalkozásoknál nem elhanyagolható.

A csekély összegü - ún. de minimis - támogatás nyújtásakor a támogatást adónak teljes szabadsága van a támogatás egyéb szabályainak megállapításakor (pl. elszámolható költségek, támogatási intenzitás).

8. A képzési támogatás megengedett a 68/2001/EK (Commission Regulation 2001:20) csoportmentességi rendelet alapján.

9. A munkahelyteremtéshez kötött támogatás megengedett a munkavállalói támogatásokra vonatkozó közösségi iránymutatás szerint (Guidelines 1995; Commission Regulation 2002).

10. Kockázatitőke-tevékenységhez adható támogatás, mind a befektetők, mind a vállalkozások részére (Information 2001).

Az ún. csoportmentességi rendeletek 2006. december 31-ig maradnak érvényben, ezért ezek a támogatások - pl. képzési, kis- és középvállalkozásokra vonatkozó, foglalkoztatási, környezetvédelmi támogatások - csak eddig az időpontig vehetők igénybe. (Ügyelni kell arra is, hogy 2005. január 1-jétől megváltozott a kis- és középvállalkozások definíciója ${ }^{9}$, emelkedtek az értékhatárok.)

\footnotetext{
${ }^{9}$ Középvállalkozás: 250 fönél kevesebbet foglalkoztat, vagy éves árbevétele nem haladja meg az 50 millió eurót, vagy éves mérlegföösszegük nem haladja meg a 43 millió eurót. Kisvállalkozás: 50 fönél kevesebbet foglalkoztat, vagy éves árbevétele nem haladja meg az 10 millió eurót, vagy éves mérlegföösszegük nem haladja meg a 10 millió eurót. Mikrovállalkozás: 10 fónél kevesebbet foglalkoztat, vagy éves árbevétele nem haladja meg az 2 millió eurót, vagy éves mérlegfóösszegük nem haladja meg a 2 millió eurót.
} 
Az acélipari vállalkozások, különösen az alaptechnológiát müködtetö vaskohászati társaságok alapvetően nem a kis- és középvállalati körbe tartoznak, ezért számukra nagyon szűkösek a lehetőségek. Komolyabb fejlesztési forrásokat részükre, egyedül az ESZAK vagyonának átcsoportosításával létrehozott Európai Szén- és Acélkutatási Alap biztosíthat.

\section{Az Európai Szén- és Acélkutatási Alap}

A kutatás-fejlesztés az acélipar jelenlegi támogatási formái között kiemelt figyelmet érdemel, hiszen az ESZAK teljes vagyona és a kezeléséböl keletkező bevétel az ún. Szén- és Acélkutatási Alapba (Research Fund for Coal and Steel) került át 2003-ban.

Az Európai Szén- és Acélközösség a két ágazat müködését felügyelte, koordinálta a termelést, pénzügyi kölcsönöket és garanciákat nyújtott különböző jogcímeken, melyek között a kutatás-fejlesztés már korábban is jelentős szerepet játszott. Az 50 éves fennállás alatt, több innovatív technológia kidolgozását és ipari bevezetését támogatták, aminek eredményeként az Unió az évezred végére a világ egyik legkorszerübb acéliparát mondhatta magáénak.

A vaskohászati fejlesztések legfontosabb területei (melyek ma is aktuálisak) a következők voltak:

1. ércredukció $\Rightarrow$ új vasszivacsgyártó és olvadékredukciós-eljárások kísérletei, gyakorlati megvalósítása;

2. acélgyártás $\Rightarrow \mathrm{a}$ konverteres acélgyártás továbbfejlesztése (metallurgiai és hőtechnikai munka optimalizálása), az elektroacélgyártás termelékenységének növelése, energia felhasználásának csökkentése;

3. végméretközeli öntés $\Rightarrow$ az alaptechnológiának a nagyolvasztó + konverter + folyamatos öntőgép vagy az elektrokemence + vékonybramma gyártósor tekinthetö, a végtermék 0,8-1 mm vastag hengerelt szalag (ultravékony méretü melegen hengerelt szalag) ${ }^{10}$

Az öntés és a hengerlés közvetlen összekapcsolása jelentős elörelépést hozott a kihozatal, az energiamegtakarítás és a termelési költségek csökkentése terén. Ezt a korszakalkotó technológiát nevezik vékonybramma-öntésnek (TSC $\Rightarrow$ thin slab casting). A modern vékonybramma-öntő eljárás eredete az EU vaskohászatának érdeme, mégis az tapasztalható, hogy elterjedése az Unión belül lassú. Az új eljárás a kezdeti viszonylag kis kapacitással (és az egyes vélemények szerint) szűkebb minőségi választékkal eddig nem tudott beilleszkedni a régió üzemeinek sorába ${ }^{11}$. Elterjedését az is hátráltatja, hogy az Unióban viszonylag korszerü hengerművek találhatók, melyek bezárása komoly anyagi veszteséget okozna a működtető vállalatoknak. A technológiát Olaszországban, Spa-

10 Az első folyamatos ún. ultravékonyszalag-öntő és direkthengerlö berendezést 1989-ben helyezte üzembe az amerikai Nucor cég, és rögtön a hazai acélpiac egyik vezetö gyártója lett.

$"$ Egyes vélemények szerint az ún. vékonybramma-öntö nem tud minden területen versenyezni a hagyományos öntögépekkel. A kristályosítóban fellépő túlzott turbulencia ugyanis olyan brammafelszínhez vezethet, amely a készterméket alkalmatlanná teszi igényesebb termékek (pl. autókarosszéria) elöállitására. Egy hagyományos öntőgép választéka - ez idő szerint- tehát szélesebb, mint egy vékonybramma-öntögépé. A további kutatások a technológia tökéletesítésére irányulnak. 
nyolországban, Németországban, Hollandiában és Csehországban alkalmazzák üzemi méretekben ${ }^{12}$.

Az Európai Szén- és Acélközösség feladatainak ellátásához a termelőktől - az alapító okirat felhatalmazása alapján - forgalomarányosan adót szedhetett be, így a közösségi költségvetéstöl teljesen független pénzügyi forrással rendelkezett. A támogatási igények fokozatos csökkenése miatt ez a gyakorlat végül megszünt (1998-ban), de a Szerződés lejártakor vagyona így is jelentős, 1,6 milliárd euró értéket képviselt. Az Európai Közösség ezt a vagyont a közös kutatás-fejlesztési alapokba kívánta beolvasztani, amit a befizető országok vállalatainak és a szakmai szervezeteknek (pl. IISI, Eurofer ${ }^{13}$ ) sikerült megakadályozniuk.

Az ESZAK eszközeit az Európai Közösség átvette (Szén- és Acélkutatási Alap vagyona megjelöléssel), de azt elöírták, hogy a teljes tőkét meg kell ôrizni, és csak a vagyon kezeléséből származó jövedelem, évente kb. 60 millió euró használható fel. Ez a bevétel csak meghatározott célra, 27,2\%-ban a szénbányászati, 72,8\%-ban az acélipari kutatási projektek finanszírozására fordítható, és nem csoportosítható át más költségvetési tételekbe. Fenntartották viszont annak a lehetőségét, hogy a Tanács szükség esetén az ágazati kutatások közötti százalékos megoszlást egyhangú határozattal megváltoztathatja.

Ilyen elözmények után hozták létre 2003-ban a Szén- és Acélkutatási Alapot (Research Fund for Coal and Steel) (Council Decision 2003:22, 25, 28).

A 2004-ben csatlakozott új uniós országok részvétele a programban sokáig nem volt tisztázott, hiszen a vagyon létrehozásában nem vettek részt. Végül megegyezés született arról, hogy 2006-2009 között meghatározott összeggel hozzá kell járulniuk az Alap müködéséhez, és így már a belépéstől számítva jogosultak az Alap igénybevételére.

Elsősorban azok a kutatási területek számíthatnak támogatásra, amelyek az alapanyag- és energiafelhasználás optimalizálására, a környezetkímélőbb gyártásra, a szenynyezés csökkentésére és az újrahasznosításra irányulnak ${ }^{14}$.

A Nizzai Szerződésnek az Európai Szén- és Acélközösség megszűnésével foglalkozó Jegyzőkönyve elöírta, hogy a vagyont - pontosabban ennek hozadékát - csak a szénés acélipari kutatásokra lehet felhasználni és ezért ezen a területen különleges szabályokat kell kidolgozni.

A szigorú állami támogatási szabályok fellazulása a horizontális közösségi szintű támogatásoknál nem várható. Elképzelhető azonban a kutatás-fejlesztés területén, ahol először 2007-ben fogják értékelni a program tapasztalatait, és ha szükséges módosíthatják a jelenlegi szabályokat.

12 Arvedi, AST, Olaszország $\Rightarrow$ 0,7 millió tonna/év ill. 1 millió tonna/év; ACB, Spanyolország $\Rightarrow 1,9$ millió tonna/év; Thyssen, Németország $\Rightarrow 2$ millió tonna/év; Hoogovens, Hollandia $\Rightarrow 1,2$ millió tonna/év. Az új tagországok közül egyedül a Csehországban található egy kb. 1 millió tonna/év kapacitású üzem. A világon a legnagyobb kapacitású (2,7 millió tonna/év) üzem Tajvanon müködik.

13 Az Unió legnagyobb acélgyártói 1976-ban hozták létre az Európai Acélkereskedelmi Szervezetet EUROFER néven (European Confederation of Iron and Steel Industries). Az EUROFER legfontosabb feladatai között szerepelt a kapacitás-és a termeléscsökkentés összehangolása, valamint a végrehajtás ellenörzése.

${ }^{14}$ A közös európai érdeket szolgáló fontos projektek egyaránt támogathatók az Unió Kutatás-Fejlesztési Keretprogramjából és a Szén- és Acélkutatási Alapból. Az alacsony $\mathrm{CO}_{2}$ kibocsátású acélgyártó eljárások kidolgozásához például mindkét Alap jelentős összeggel járult hozzá 2003-2004 között (VI. Kutatási Keretprogram 20 millió euró, Szénés Acélkutatási Alap 5 millió euró). 


\section{Kivételek a szigorú szabályok ellenére?}

Az ESZAK Szerződés megszűnésével az ágazat vállalatai számára a működési, megmentési célú támogatás nyújtása egyértelmüen tiltott, a Római Szerződés értelmében. A lobbitevékenységnek köszönhetően kivételek azonban mindig vannak. Három új uniós országban - Lengyelország, Csehország és Szlovákia - a technikai modernizáció, a szociális problémák és a pénzügyi helyzet rendezésére továbbra is engedélyezett az acélipar állami támogatása 2006-ig, illetve Szlovákiában 2010-ig. Alapvetően a privatizációt kívánják elösegíteni egy meghatározott vállalati körnél (lásd OECD 2. számú javaslata).

A Bizottság már a csatlakozást megelözően többször hangsúlyozta, hogy az új tagországok közül különösen a visegrádi országokban (nem kezelik külön Magyarországot!) az acélipar területileg koncentrált, mivel az acéltermelés $40 \%$-át egy ipari háromszögben, a lengyel, a cseh és a szlovák határ közelében állítják elő és az elöállított termékek nem versenyképesek. Ennek a versenyképtelen és koncentrált acéliparnak az átalakítása súlyos gazdasági és társadalmi kérdések kezelését igényli, ezért hatékony társadalmi párbeszédre van szükség a sikeres modernizáció és a versenyképes minőség garantálásához (Opinion 2001, 2003). Ez volt az oka annak, hogy a három országban az ESZAK megszünését követően is engedélyezték az acélipar állami támogatását.

A tagállamok állami támogatást csak a Bizottságnak történő előzetes bejelentés után, annak jóváhagyása után nyújthatnak. Ez a kritérium teljesült, hiszen a támogatások feltételrendszerét az érintett országok csatlakozási szerződéseiben pontosan rögzítették (Acts of Accession 2003). Ezt megelőzően a lengyelek és a csehek vállalatokra lebontott nemzeti szerkezetátalakítási programot készítettek, amit a Bizottság csak többszöri egyeztetés után fogadott el. Szlovákia nem készített ilyen programot, de megegyezett a Bizottsággal arról, hogy szociális célokra és a technológia korszerüsitésére 2010-ig támogatást nyújthat acéliparának.

A következőkben a lengyel és a cseh állami támogatásokhoz kapcsolódó kapacitásés létszámcsökkentési feltételek láthatók:

Állami támogatások az acéliparban (2002-2006)

1. táblázat

\begin{tabular}{|l|c|c|c|}
\hline Lengyelország & 836 millió euró & $\begin{array}{c}1,35 \text { millió tonna } \\
\text { kapacitáscsökkentés }\end{array}$ & $\begin{array}{c}8.000 \text { fö elbocsátása } \\
(2002-2006)\end{array}$ \\
\hline Csehország & 453 millió euró & $\begin{array}{c}0,59 \text { millió tonna } \\
\text { kapacitáscsökkentés }\end{array}$ & $\begin{array}{c}6.000 \text { fó elbocsátása } \\
(2002-2010)\end{array}$ \\
\hline
\end{tabular}

Forrás. European Commisssion

A szerkezetátalakításhoz továbbra is üzembezárások és ezzel összefüggő elbocsátások kapcsolódnak.

A Bizottság tehát kizárólagos hatáskörével élve jóváhagyta a támogatási igényeket annak ellenére, hogy erre már nem lett volna lehetőség a Római Szerződés szerint.

Az elöírt feltételek betartását azonban szigorúan ellenőrizni kívánja, szükség esetén szankciók bevezetésétől sem riad vissza, ahogyan ezt Lengyelország és Csehország alábbi példája is szemlélteti. 
A Bizottság felülvizsgálta a Huta Czestochowa S.A. (HCz) - Lengyelország második legnagyobb acélgyártója - részére nyújtott állami támogatás jogosságát.

A HCz pénzügyi problémáinak kezelésére az állam új társaságot alapított, és leírta a cég adósságát szerkezetátalakítás címén. A kereskedelmi hitelezők ezután követelésük fejében részesedést szerezhettek az új társaságban. Ilyen megállapodásra került sor a PHS - Polsky Huty Stali S. - új tulajdonosával, az LNM holdinggal is. A PHS viszont 1997-2003 között már részesült 590 millió euró állami támogatásban a privatizációt megelőzően (Report 2004). Felmerült a kérdés, hogy jogosult volt-e az LNM a HCz részvényeinek megszerzésére?

Ugyanakkor a csatlakozási szerződésnek, a lengyel acélipar szerkezetátalakításáról szóló 8. sz. jegyzőkönyve megtiltja a HCz számára a szerkezetátalakítási támogatás nyújtását.

Amennyiben bebizonyosodik, hogy a $\mathrm{HCz}$ további támogatásokat kapott, az EK szerződés 88 . cikke (2) bekezdése alapján az előírt hivatalos vizsgálati eljárás után az érintett vállalkozásoknak vissza kell téríteniük a folyósított támogatásokat (State Aid - Poland 2004).

A cseh Třinecké Železárny-t (TŽ) a 90-es évek közepén privatizálták és állami támogatás igénybevétele nélkül, teljes szerkezetátalakítást hajtottak végre a társaságnál. A cseh kormány 2004-ben rendeletet fogadott el, amely kimondta, hogy a (TŽ) birtokában lévő ISPAT Nova Hut (INH) részvényeket megadott áron megvásárolja. A versenyhivatal engedélyezte a tranzakciót, és így a Třinecké Železárny összesen kb. 20 millió euró értékben jutott környezetvédelemre, kutatás-fejlesztésre, képzésre és üzembezárásra fordítható állami támogatáshoz. A cseh acélipar szerkezetátalakításáról szóló jegyzőkönyvben (Act of Accession Portocol Nr. 2.) viszont a TŽ nincs felsorolva a támogatásra jogosult vállalatok között. Annak ellenére tehát, hogy elviekben a fenti jogcímek alapján igényelhető támogatás, a Bizottság megnyitotta a hivatalos vizsgálati eljárást. Értelmezésében ez illegális szerkezetátalakítási támogatásnak minősül (State Aid - Czech 2005).

A Bizottság a 88. cikk (2) bekezdés szerint eljárás megindítását kezdeményezheti, ha kétségei vannak afelöl, hogy a jelzett támogatási intézkedés nem összeegyeztethető a közös piaccal. Ilyen esetben a Bizottság „formális vizsgálatot” kezd. A Hivatalos Lapban (Official Journal) nyilvánosságra hozza a támogatás leírását, és felkéri az érintett tagállamokat, valamint az érdekelt feleket észrevételeik megtételére. Ennek eredménye vagy pozitív (a támogatást meg lehet valósítani), vagy negatív (a támogatást nem lehet végrehajtani), vagy feltételekhez kötötten pozitív (a támogatást bizonyos feltételek teljesítése esetén lehet megvalósítani). A vizsgálat várható időtartama legfeljebb 18 hónap. Az Alapszerződés 230 cikke alapján minden döntés az Európai Bíróság felülvizsgálatának tárgya lehet. 
A kivételeket tehát nagyon szigorúan próbálják ellenőrizni, és ha a vizsgálat eredménye elmarasztaló, a meghozott határozatok visszamenőleges hatályúak. A jelenlegi eljárási szabályok szerint a Bizottság köteles elrendelni minden a közös piaccal összeegyeztethetetlen, törvénytelen, támogatás visszafizettetését. Nem valószínüsíthető, hogy az új tagállamok a jövőben hasonló engedményben részesülhetnek, korszerütlen acéliparukra való hivatkozással ${ }^{15}$.

Az eddig megtett intézkedések azonban nem a várt eredményt mutatják. A Bizottság 2005. augusztusában megállapította, hogy a cseh és a lengyel reformok nem elég gyorsak, a kedvező acélpiaci körülmények ellenére. Az állami támogatások feltételeként elöírták, hogy az érintett vállalatok 2006. végére nyereségesen müködjenek, de ennek egyelőre kicsi a realitása, ezért sürgetik a reformok megvalósítását.

\section{Az Unió acélipara az ESZAK megszünése után}

Az Európai integráció első szektorális politikájának jogi kereteit a Párizsi Szerződéssel létrehozott Európai Szén- és Acélközösség alakította ki. Ez a közösségi politika különböző termelés- és piacszabályozási, és az ezen belüli támogatási rendszerre épült. Több olyan szabályozási elemet foglalt magában, amely a maga idejében segítette a szénbányászat és az acélipar fejlődését és a válságokból való kilábalást. Az acéliparban az ESZAK ún. Főhatósága termelési kvótákat és minimálárakat állapíthatott meg a közösség egész területére, ami tulajdonképpen piacszabályozási célú ágazati beavatkozás volt. A termelés korlátozása mellett, központi intézkedéseket hozhatott a különösen veszteséges kapacitások tervszerü leépítésére és a megmaradó termelési technológiák átalakítására is.

$\mathrm{Az}$ acélipar közel 30 évig tartó, sokszor fájdalmas válságkezelése során az adott feladat megoldására közösségi szintű programokat dolgoztak ki, melyek elsősorban a kínálati oldal további gyengülésének megakadályozására szolgáltak. Ezért éri számos olyan kritika a nyugat-európai acélipart, hogy csak nagy állami támogatással maradhatott életben. A kritika mellett azt is el kell ismerni, hogy az ezredforduló uniós acélipara a nemzetközi versenyben is megállja a helyét. A felesleges, korszerütlen kapacitásokat leépítették, és kezelték a létszámcsökkentésből eredő szociális feszültségeket. Az acélipar szerkezetátalakításának befejeződésével a legfontosabb megoldandó kérdések már a környezetvédelemre, a munka biztonság növelésére és a termékminőség javítására összpontosítanak. (Az újabb kihívást a 2004-ben csatlakozott országok korszerütlen acélipara jelenti.)

A 90-es évek közepén megindult liberalizáció folytatásaként, az Unió szénbányászatát és acéliparát sajátos szempontok szerint kezelő ESZAK Szerződést 2002. július 23-án megszüntették. Az egyezmény eredetileg 50 évre szólt, de még az évtized végén sem volt tisztázott, hogy meghosszabbítják-e vagy a szektor szabályozását egyszerüen a Római Szerződés alá rendelik. Ez utóbbi történt, ami az állami támogatási szabályok szigorodásával járt együtt. Az új lehetőségek a regionális és a szerkezetátalakítási támogatást megtiltják, a bezárási támogatást pedig csak átmeneti ideig engedik. A kis és középvállalkozások csoportmentességi rendeletei alapján, számos jogcímen - pl. képzés,

15 Magyarország nem kért derogációt acéliparának támogatására, és 1997-től gyakorlatilag megszűnt a támogatás. Elötte viszont több mint 70 milliárd forintot fordítottak a korszerüsítésre, a szociális kérdések kezelésére, igazán átütö eredmények nélkül. 
munkahelyteremtés, tanácsadás, beruházás, kutatás-fejlesztés - igényelhetők támogatások, de az acélipari vállalkozások döntően nem ebbe a kategóriába tartoznak, tőkeigényük magas, költséges technológiákat működtetnek.

Nagyobb lehetőségeket rejt magában az ESZAK megszünése után létrehozott Szén- és Acélkutatási Alap, amely kizárólag a két ágazat kutatás-fejlesztési elképzeléseinek megvalósítását támogatja.

Az ESZAK feladatainak ellátásához független költségvetéssel rendelkezett, melyhez a szükséges forrást a felügyelete alatt tevékenykedő vállalatok több évtizedes befizetései (adók formájában) biztosították. A támogatások után fennmaradó, jelentős közel 1,6 milliárd euró vagyon átkerült ebbe az alapba és a kezeléséből származó bevételek használhatók fel, évente kb. 60 millió euró nagyságrendben. Az ágazat vállalatai és a szakmai szervezetek sikerének könyvelhető el, hogy az eredeti elképzelés szerinti, az EU Kutatás-Fejlesztési Keretprogramjába való beolvasztás nem valósulhatott meg. Azt is sikerült elérni, hogy a támogatások igénybevételéhez speciális szabályrendszert dolgoztak ki, melyet szükség esetén módosíthatnak.

Az Európai Szén- és Acélközösség nyomdokain tovább haladva, ha szűkebb területen is, de mégis sikerült valamilyen ágazati szabályozást fenntartani, ami remélhetőleg hozzá járul majd az uniós acélipar eddig elért modernizációs eredményeinek fenntartásához, továbbfejlesztéséhez.

\section{Hivatkozások}

Act concerning the conditions of accession of the Czech Republic, the Republic of Estonia, the Republic of Cyprus, the Republic of Latvia, the Republic of Lithuania, the Republic of Hungary, the Republic of Malta, the Republic of Poland, the Republic of Slovenia and the Slovak Republic and the adjustments to the Treaties on which the European Union is founded - Protocol No 2 on the restructuring of the Czech Steel Industry, OJ L 236, 23. 9. 2003, 934-939.

Act concerning the conditions of accession of the Czech Republic, the Republic of Estonia, the Republic of Cyprus, the Republic of Latvia, the Republic of Lithuania, the Republic of Hungary, the Republic of Malta, the Republic of Poland, the Republic of Slovenia and the Slovak Republic and the adjustments to the Treaties on which the European Union is founded - Protocol No 8 on the restructuring of the Polish steel industry, OJ L 236, 23. 9. 2003, 948-953.

Commission Decision No 2496/96/ECSC of 18. 12. 1996. establishing Community rules for State aid to the steel industry, OJ L338, 28. 12. 1996, 42-47.

Commission Regulation (EC) No 2031/2001 of 6 August, 2001, amending Annex I to Council Regulation (EEC) No 2658/87 on the tariff and statistical nomenclature and on the Common Customs Tariff, OJ L279, 23. 10. 2001, 1-944.

Commission Regulation (EC) No 2204/2002 of 12 December, 2002 on the application of Articles 87 and 88 of the EC Treaty to State aid for employment, HL L337, 13. 12. 2002, 3-14.

Commission Regulation (EC) No 364/2004 of 25 February, 2004 amending Regulation (EC) No 70/ 2001 as regards the extension of its scope to include aid for research and development, OJ L63, 28. 02. 2004, 22-28.

Commission Regulation (EC) No 68/2001 of 12 January, 2001 on the application of Articles 87 and 88 of the EC Treaty to training aid, OJ L10, 13. 1. 2001, 20-29.

Commission Regulation (EC) No 69/2001 of 12 January 2001 on the application of Articles 87 and 88 of the EC Treaty to de minimis aid, OJ L10, 13. 1. 2001, 30-32.

Commission Regulation (EC) No 70/2001 of 12 January 2001 on the application of Articles 87 and 88 of the EC Treaty to State aid to small and medium-sized enterprise, OJ L10, 13. 1. 2001, 33-42.

Communication from the Commission, Multisectoral framework on regional aid for large investment projects, OJ C70, 19. 03. 2002, 8-20. 
Communication from the Commission, rescue and restructuring aid and closure aid for the steel sector, OJ C 70. 19. 03. 2002, 21-22.

Community guidelines on State aid for environmental protection, OJ C74, 10. 3. 1998, 9-31.

Community guidelines on State aid for environmental protection, OJ C37, 3. 02. 2001, 3-15.

Community guidelines on State aid for rescuing and restructuring firms in difficulty, OJ C244, 1. 10. 2004.

Council Decision (EC) No 2003/76 of 1 February, 2003 establishing the measures necessary for the implementation of the Protocol, annexed to the Treaty establishing the European Community, on the financial consequences of the expiry of the ECSC Treaty and on the Research Fund for Coal and Steel, OJ L029, 5. 2. 2003, 22-24.

Council Decision (EC) No 2003/77 of 1 February, 2003 laying down multiannual financial guidelines for managing the assets of the ECSC in liquidation and, on completion of the liquidation, the Assets of the Research Fund for Coal and Steel, OJ L029, 5. 2. 2003, 25-27.

Council Decision (EC) No 2003/78 of 1 February, 2003 laying down the multiannual technical guidelines for the research programme of the Research Fund for Coal and Steel, OJ L029, 5. 2. 2003, 28-39.

Council Regulation (EC) No 1407/2002 of 23 July, 2002 on State aid to the coal industry, OJ L205, 2. 8. 2002, 1-8.

Council Regulation (EC) No 994/98 of 7 May 1998 on the application of Articles 92 and 93 of the Treaty establishing the European Community to certain categories of horizontal State aid, OJ L142, 14. 5. 1998, 1-4.

Denton, R. (1995): Competition Policy, European Trend.;1996, 27-33.

European Commission, Twentieth Report on Competition Policy, 1990, Paragraph 122.

Guidelines on aid to employment, OJ C334, 12. 12. 1995, 4-9.

Guidelines on national regional aid, OJ C74, 1998. 03. 10. 9-31.

Information from the Commission - Community framework for state aid for research and development, OJ C45, 17. 2. 1996, 5-16.

Information from the Commission - State aid and risk capital, OJ C235, 21. 08. 2001, 3-11.

International Iron and Steel Institute Proposal to Governments on State Aid for the Steel Industry, Brussels, 16 April, 2002.

Korah, V. (1997): An introductory Guide to EC Competition Law and Practice. Sixth Edition, Hart Publishing, Oxford.

Kormányrendelet - 85/2004. (IV. 19.) - az Európai Közösséget létrehozó Szerződés 87. cikkének (1) bekezdése szerinti állami támogatásokkal kapcsolatos eljárásról és a regionális támogatási térképről.

OECD Observer No. 236. March 2003. www.oecdobserver.org

Opinion of the Economic and Social Committee on the employment and social situation in the central and eastern European applicant states, OJ C193, 10.7.2001, 87-99.

Opinion of the European Economic and Social Committee on the economic and social consequences of enlargement in the candidate countries, OJ C85, 8.4.2003, 65-76.

Report from the Commission to the Council and the European Parliament: First monitoring report on steel restructing in the Czech Republic and Poland, COM(2004)443 final, Brussels, 7. 7, 2004.

State Aid Action Plan, Less and better targeted state aid: a roadmap for state aid reform 2005-2009, European Commission, Consultation document, 07. 2005, 1-20.

State Aid - Czech Republic, State Aid No C45/2004 (ex NN 62/2004)- Restructing aid to the Czech steel producer Třinecké Železárny a.s. (Invitation to submit comments pursuant to Article 88(2) of the EC Treaty), OJ C22, 27. 1. 2005, 2-8.

State Aid - Poland, State Aid C20/2004 (ex NN 25/2004) - Poland, restructuring aid to steel producer Huta Czestochowa SA. (Invitation to submit comments pursuant to Article 88(2) of the EC Treaty), OJ C204, 12. 8. 2004, 6-14. 